\section{Doves in false garb}

\section{The claim by the anti-nuclear movement of professional support is mostly a sham.}

Professional societies have now lost most of the characteristics of the mediaeval guilds from which they sprang. A little like trades unions, from which they are often indistinguishable, they are naturally defensive of the interests of those who happen to belong to them. On many issues, they are often at odds with the communities in which they are embedded. So how, and in what circumstances, should professional organizations set out to influence events on a wider canvas than that with which they are professionally concerned? These are some of the questions provoked by last week's meeting in London (see page 544) at which a number of informal groups set out to stimulate professional interest in the problems of nuclear disarmament. It is important, not least for professional people themselves, that the questions should be answered clearly.

In modern circumstances, professional societies have become anachronisms. The days have long since gone when they could automatically assume responsibility for deciding which individuals should be licensed to carry out professional tasks. Even in Britain, only the two halves of the legal professional retain an absolute right to determine entry into a profession; the professional registration of physicians has long since been the responsibility of the General Medical Council, while the analogous functions of the engineering institutions are about to be transferred to a more public central body (as recommended by Finniston two years ago). Other professional organizations, the Royal Institute of British Architects for example, have found it convenient to offer the public service of a means by which disappointed clients may settle claims against professional people, often as an antidote for some restrictive practice such as the enforcement of minimum fees. Others have chosen to shoulder the public burden of defining technical standards of performance, as the Institute of Electrical and Electronics Engineers does for much of the electronic equipment introduced in the United States and thus, by extension, internationally. However truncated their roles, however, most professional organizations remain valuable as learned societies and also rightly function as legitimate and beneficial pressure groups. Physicians' organizations usually have something to say about public policy on smoking and fluoridation, for example. Science, it will be remarked, is for the most part too new to have been tarred with the mediaeval brush.

But if the professional societies have been liberated from most of their statutory functions of deciding who is and is not entitled to practise as a professional, is it not all the easier for them to speak out on wider issues, military policy for example? This was the implicit assumption of last week's conference in London. The simple answer is that the expectation is over-simple. Even as things are, professional organizations are needlessly indifferent to important public issues well within the spheres in which their professional competence would command respect. Physicians have been consistently indifferent to the quality of health care (in Britain) and its cost (in the United States). In the past thirty years, members of teachers' organizations in many places have officiated at the rapid transformation of teaching practice without drawing attention to the serious social consequences that may accompany the intended benefits. Yet these are questions on which the opinions of quasi-professional organizations might be influential, even welcome. And, in their absence, opinions on wider issues, even if they could be arrived at without violence to the views of dissenting members, would cut no ice.

This is why much of last week's discussion was misplaced. The claim that the professions as such have a responsibility to alert the general public to the great issues that confront society, inflation and unemployment just as much as nuclear armaments, is unwarranted and impractical. But there is a sense in which professional people, acting individually, may be held to shoulder an extra responsibility for giving wider currency to their conclusions about important issues on which they have some special knowledge. Professional people have in the past been too mealymouthed on many important questions. Even if the question is necessarily as contentious as a nation's defence policy, they should not be afraid to say so. But professional people are mistaken to suppose that the task can be done respectably under titles such as those paraded at last week's conference. What other justification is there for the Medical Campaign against Nuclear Weapons except that physicians prefer hobnobbing with other physicians than with the hoi polloi? Or can they waywardly suppose that they may be able to capture something of the nowvanished mediaeval mystique by pretending that they are part of such an organization? The truth is that they are not, and that their attempts to invest their legitimate causes with spurious authority are a deceit, and a counter-productive one at that. If architects, physicians, teachers and scientists claim a special right to speak for their professions on nuclear weapons, they should take their courage in their hands and join Lords Brockway and Noel Baker on the hustings.

\section{Up and over the top}

\section{The United States seems not to appreciate the} damage that will be done by last week's budget.

When the United States began in the 1960s to pay for the Vietnam war by printing dollar bills, several years went by before people elsewhere fully appreciated what was happening. The result was that inflation had firmly taken hold throughout the industrialized world before governments (including that of the United States) began to take remedial action - by which time the oil-producing states had devised their own way of penalizing fiscal self-indulgence. Now the shoe is on the other foot. Thanks to the tight coupling between the major industrial markets ironically engendered by institutions such as the Eurodollar market created during the last bout of inflation exported from the United States, economies other than the American are now, if possible, almost hypersensitive to what Washington is planning. That is the simple reason why administrations elsewhere are busily planning for the inevitable rise of interest rates in the coming year; their financial markets are discounting the consequences as quickly as their courage will allow.

Even those who sympathize with the Administration's present objectives are dismayed by what is happening. In round numbers, President Ronald Reagan has asked Congress for authority to spend something like $\$ 100,000$ million more than his Administration will collect in taxes. While some of his more contentious demands may be moderated in the long months that lie ahead, he must know as well as the rest of the world that Congress will also declare itself strongly against some of the sharp curtailments of welfare expenditure now planned. So it is natural that people should already be anticipating with varying degrees of gloom the prospect of a United States deficit greater than the total revenue of any other government in the West.

But why should this matter? And how can the scientific enterprise be affected? Why should not honest researchers persist in the pursuit of understanding, confident that in the end some productive use will have been made of their findings? The snag is that it will not and cannot be so easy. The Administration must soon settle for some blend of the only two ways of dealing with the crisis it has wished upon itself - it can use higher interest rates to persuade citizens of the United States to lend their earnings to the Treasury rather than to spend them, in which case there will be a slump. Or it can print dollar bills to make up the difference between what it spends and what it collects, in which case there will certainly be high interest rates, but the slump may be avoided at the expense of established institutions - universities, foundations and the like. Mr Paul Volker at the Federal Reserve Board would prefer the first course. Most politicians would prefer the second. Other people, other institutions and the research enterprise as a whole will suffer either way. 